University of Nebraska - Lincoln

DigitalCommons@University of Nebraska - Lincoln

Faculty Publications: Department of Entomology

4-1-1999

\title{
Baseline Susceptibility of European Corn Borer (Lepidoptera: Crambidae) to Bacillus thuringiensis Toxins
}

\author{
Paula C. R. G. Macron \\ University of Nebraska-Lincoln \\ Linda J. Young \\ University of Nebraska - Lincoln, lyoung3@unl.edu \\ Kevin L. Steffey \\ University of Nebraska-Lincoln \\ Blair Siegfried \\ University of Nebraska-Lincoln, bsiegfried1@ufl.edu
}

Follow this and additional works at: https://digitalcommons.unl.edu/entomologyfacpub

Part of the Entomology Commons

\footnotetext{
Macron, Paula C. R. G.; Young, Linda J.; Steffey, Kevin L.; and Siegfried, Blair, "Baseline Susceptibility of European Corn Borer (Lepidoptera: Crambidae) to Bacillus thuringiensis Toxins" (1999). Faculty Publications: Department of Entomology. 60.

https://digitalcommons.unl.edu/entomologyfacpub/60
}

This Article is brought to you for free and open access by the Entomology, Department of at DigitalCommons@University of Nebraska - Lincoln. It has been accepted for inclusion in Faculty Publications: Department of Entomology by an authorized administrator of DigitalCommons@University of Nebraska - Lincoln. 


\title{
Baseline Susceptibility of European Corn Borer (Lepidoptera: Crambidae) to Bacillus thuringiensis Toxins
}

\author{
PAULA C.R.G. MARÇON, ${ }^{1}$ LINDA J. YOUNG, ${ }^{2}$ KEVIN L. STEFFEY, ${ }^{3}$ AND BLAIR D. SIEGFRIED ${ }^{4}$ \\ Department of Entomology, 202 Plant Industry Building, University of Nebraska, Lincoln, NE 68583-0816
}

\begin{abstract}
J. Econ. Entomol. 92(2): 279-285 (1999)
ABSTRACT Susceptibility to CrylAb and CrylAc toxins from Bacillus thuringiensis was determined for 11 populations of neonate European corn borer,Ostrinia nubilalis (Hübner), from the United States and 1 from northern Italy. Corn borer larvae were exposed to artificial diet treated with increasing $B$. thuringiensis concentrations, and mortality and growth inhibition were evaluated after $7 \mathrm{~d}$. The range of variation in $B$. thuringiensis susceptibility indicated by growth inhibition was very similar to that indicated by mortality. Although interpopulation variation in susceptibility to both proteins was observed, the magnitude of the differences was small ( $\leqslant 4$-fold) and comparable to the variability observed among generations within a particular population $(\leq 3$-fold). Additionally, there was no indication that $B$. thuringiensis susceptibility was influenced by pheromone race, voltine ecotype, or geographic location. These results suggest that the observed susceptibility differences reflect natural variation in $B$. thuringiensis susceptibility among corn borer populations rather than variation caused by prior exposure to selection pressures. Therefore, European corn borers apparently are susceptible to $B$. thuringiensis toxins among populations across most of their geographic range.
\end{abstract}

KEY WORDS Bacillus thuringiensis, Ostrinia nubilalis, geographic variability, bioassay

INCREASING PUBLIC CONCERNS about environmental hazards and widespread resistance in pest populations are threatening the continued effectiveness of conventional insecticides and should increase the use of insecticidal products derived from Bacillus thuringiensis Berliner (Bt) in the next decade (Tabashnik 1994). This is particularly true for transgenic Bt crops, which represent an important new tool for pest management (Fischhoff 1996). However, increased use of $B$. thuringiensis in agriculture via transgenic plants and other modes of application likely will increase the intensity of selection for $B$. thuringiensis resistance in pest populations. The development of $B$. thuringiensis resistance in target pests threatens the continued effectiveness of $B$. thuringiensis technology, both as transgenic Bt plants and all other B. thuringiensisbased products. The possibility of resistance development highlights the need to develop and implement resistance management strategies to prevent or delay the evolution of resistance to $B$. thuringiensis (Hokkanen and Wearing 1994). These strategies are dependent on the development of effective resistance monitoring programs capable of early detection of resistance that will allow implementation of appropri-

\footnotetext{
${ }^{1}$ Current address: DuPont Agricultural Products, Stine-Haskell Research Center, Elkton Rd., P.O. Box 30, Newark, DE 19714.

${ }^{2}$ Department of Biometry, 103 Miller Hall, University of NebraskaLíncoln, Lincoln, NE 68583.

${ }^{3}$ Department of Crop Sciences, S-322 Turner Hall, 1102 South Goodwin Avenue, University of Illinois, Urbana, IL 61801.

${ }^{4}$ To whom correspondence should be addressed.
}

ate management decisions in a timely manner (Dennehey 1987). The initial steps in implementing such programs include development of appropriate bioassay techniques and establishment of baseline susceptibility data among populations across the geographic range of the target species. With this information, potential changes in susceptibility of populations in response to selection with $B$. thuringiensis can be identified (Fischhoff 1996).

The European corn borer, Ostrinia nubilalis (Hübner), is one of the most destructive pests of maize, Zea mays L., in the United States (Mason et al. 1996) and the major target pest for control with transgenic Bt corn (Fischhoff 1996). Two pheromone races of European corn borer have been identified in North America-the $Z$ race predominates over most of the range in Europe and North America, whereas the $E$ strain is found in Switzerland, Italy, and eastern North America from Massachusetts to South Carolina (Klun and Huettel 1988, Mason et al. 1996). Additionally, Showers (1993) recognized 3 European corn borer voltine ecotypes in the United States-northern univoltine, central bivoltine, and southern multivoltine. The $E$ pheromone race has bi- and multivoltine ecotypes, whereas the $Z$ race occurs as uni-, bi-, and multivoltine ecotypes (Glover et al. 1991).

Although population variability in response to $B$. thuringiensis toxins has been assessed previously in European corn borer (Siegfried et al. 1995), variation in susceptibility among geographically distinct populations, pheromone races, and voltine ecotypes has not been 
Table 1. Source description of European corn borer populations used to establish baseline susceptibility to Cryl Ab and Cry 1 Ac from B. thuringiensis

\begin{tabular}{|c|c|c|c|c|}
\hline Source & Location & Life stage & Host & Date \\
\hline Colorado & Washington Co. & Eggs-larvae & Field corn & Aug. 1995 \\
\hline Illinois & McLean Co. & Larvae & Field corn & June 1995 \\
\hline Indiana & Tippecanoe Co. & Larvae & Field corn & July 1995 \\
\hline Iowa & Polk Co. & Larvae & Field corn & July 1995 \\
\hline Laboratory, $\mathbf{N E}^{n}$ & Saunders Co. & Adults & Field corn & June 1994 \\
\hline Laboratory, $\mathrm{ICI}^{b}$ & Lombardia, Italy & Larvae & Field corn & June 1993 \\
\hline Missouri & Pemiscot Co. & Larvae & Field corn & Sept. 1995 \\
\hline N. Carolina & Washington Co. & Eggs-Larvae & Potatoes & June 1995 \\
\hline N.-Central Italy & Lombardia, Italy & Larvae. & Field corn & July 1995 \\
\hline N. Dakota univoltine & Burleigh Co. & Larvae & Field corn & July 1995 \\
\hline N. Dakota bivoltine & Burleigh Co. & Larvae & Field corn & July 1995 \\
\hline Nebraska & Saunders Co. & Adults & Field corn & June 1995 \\
\hline Pennsylvania & Snyder Co. & Larvae & Sweet corn & June 1995 \\
\hline Tennessee & Obion Co. & Larvae & Field corn & June 1995 \\
\hline
\end{tabular}

${ }^{a}$ University of Nebraska laboratory colony in culture for 14 generations.

${ }^{b}$ ICI laboratory colony in culture for 20 generations.

investigated. The objective of the current study was to establish a baseline of susceptibility to CrylAb and CrylAc toxins from geographically distinct populations of com borers, emphasizing areas where previously identified pheromone races and voltine ecotypes are known to occur.

\section{Materials and Methods}

Insect Rearing. Rearing procedures for European corn borer were based on those developed at the USDA-ARS Corn Insects Research Unit, Ames, IA (Guthrie et al. 1965). Larvae were reared at $27 \pm 0.7^{\circ} \mathrm{C}$ in a photoperiod of $24: 0(\mathrm{~L}: \mathrm{D}) \mathrm{h}$ and $80 \% \mathrm{RH}$ on a wheat germ-based diet (Lewis and Lynch 1969). At pupation, insects were moved to mating cages where adults were maintained with 8 -h scotophase at $18 \pm$ $0.7^{\circ} \mathrm{C}$ and $16-\mathrm{h}$ photophase at $27 \pm 0.7^{\circ} \mathrm{C}$ with $80 \% \mathrm{RH}$. Cages were misted with water twice a day, and adult diet was provided to maximize egg production (Leahy and Andow 1994). Egg masses were collected and incubated within plastic petri dishes containing moistened filter paper until hatching.

Field Collections. European corn borers were collected from com fields in 10 states across the United States (Colorado, Illinois, Indiana, Iowa, Missouri, Nebraska, North Carolina, North Dakota, Ohio, and Pennsylvania) and from northern Italy (Table 1). Collection sites were concentrated in areas populated with the bivoltine $\mathrm{Z}$ race, which is the dominant race throughout the Midwest (Mason et al. 1996). Additional collections were made from areas where the univoltine $\mathrm{Z}$ race (North Dakota) and the multivoltine $E$ race (North Carolina) have been previously identified (Mason et al. 1996). Of the larvae collected from North Dakota in mid-July (1st field generation), those that did not pupate were considered to represent primarily univoltine individuals. These larvae were maintained in the dark at $10^{\circ} \mathrm{C}$ for $120 \mathrm{~d}$, and then at $30^{\circ} \mathrm{C}$ and $16: 8(\mathrm{~L} \cdot \mathrm{D}) \mathrm{h}$ with $1 \%$ agar solution as a moisture source to terminate diapause and allow pupation. Two laboratory colonies also were evaluated (Table 1). The laboratory colony from Nebraska was established in 1994 and was collected from the same field site where Nebraska European corn borer were collected in 1995. This colony was tested at generation $\mathrm{F}_{14}$. The ICI laboratory colony was established in 1993 from European corn borer larvae collected in the Lombardia region of north-central Italy. This colony is maintained by ICI, and egg masses from generation $\mathrm{F}_{20}$ were sent to our laboratory. Neonates hatching from these egg masses were tested. Additionally, insects collected in 1995 from Nebraska and North Carolina were tested for 2 or 3 consecutive generations $\left(F_{1}-F_{3}\right)$ to evaluate variation in response among generations of a single population.

Field collections of $\approx 250$ individuals were obtained from each site, and colonies were initiated with no fewer than 50 founder parents. Field-collected larvae, neonates from field-collected egg masses, or neonates from egg masses produced by field-collected females were placed immediately on artificial diet in individual containers to minimize possible spread of disease. Larvae were reared to adults, and the adults were allowed to mate. Egg masses from mated females were collected and allowed to hatch. Neonates obtained from field-collected parents $\left(F_{1}\right)$ were used in most bioassays. In a few instances where egg production was low, neonates from the $F_{2}$ or $F_{3}$ generation were used (specifically Missouri, Tennessee, and Italy).

Bioassays. All bioassays were conducted by exposing neonates $(<24 \mathrm{~h}$ after hatching) to treated artificial diet. Bioassays involved surface treatment of single wells of artificial diet to minimize the amount of $B$. thuringiensis required. The rearing diet developed for Heliothis virescens (King et al. 1985) and adapted for European corn borer (Bruce Lang, Mycogen Seeds, personal communication) was used instead of corn borer diet for $B$. thuringiensis bioassays because it was relatively inexpensive, required less time for preparation, and larval growth was comparable to growth on the standard rearing diet through the first several instars (B.D.S., unpublished data).

Bioassays were performed in 128-well trays (each well $16 \mathrm{~mm}$ diameter, $16 \mathrm{~mm}$ high; CD International, Pitman, NJ). Approximately $1 \mathrm{ml}$ of diet was dispensed into each well and allowed to solidify. Eight to nine 
concentrations of toxin were used, and dilutions were made in $0.1 \%$ Triton- $\mathrm{X} 100$ nonionic detergent to obtain uniform spreading onto the diet surface. Each well was treated with $30 \mu \mathrm{l}$ of the appropriate solution. Control treatments consisted of diet treated with $0.1 \%$ Triton-X 100 only. Wells were allowed to air dry for $1 \mathrm{~h}$, and 1 neonate was transferred into each well. Wells then were covered with vented lids (CD International), and trays were held at $27^{\circ} \mathrm{C}, 24 \mathrm{~h}$ scotophase, and $80 \% \mathrm{RH}$. Mortality and individual larval weights were recorded 7 d later. When mortality was recorded, larvae that had not grown beyond lst instar and weighed $\leq 0.1 \mathrm{mg}$ were considered to be dead. As a result, the criterion for mortality used in this study accounts for both severe growth inhibition and death.

Two B. thuringiensis toxins were tested, CrylAb and CrylAc. Purified Crylab was obtained from the $B$. thuringiensis kurstaki HDl-9 strain, which produces only the CrylAb protein. This material was provided by Ciba Geigy (Research Triangle Park, NC). The crystal protein preparation was obtained by density gradient centrifugation and contained $\approx 98 \%$ crystal protein, as determined by phase contrast microscopy. CrylAc was obtained from the commercial B. thuringiensis kurstaki MVP Bioinsecticide formulation (Mycogen, San Diego, CA), which contains a modified CrylAc protein produced by a recombinant strain of the bacterium Pseudomonas flurescens. MVP Bioinsecticide contains only the CrylAc toxin and does not contain spores or any other potentially toxic ingredients (Gould et al. 1995). Nevertheless, a washing procedure was used to eliminate most inert ingredients present in the formulation. This procedure involved centrifugation of $1-\mathrm{ml}$ batches of commercial product at $10,000 \times g$ for $30 \mathrm{~s}$. The supernatant was discarded and the pellet was resuspended in double-distilled water to $1 \mathrm{ml}$ total volume. This material was centrifuged again for $30 \mathrm{~s}$, the supernatant was removed, and the pellet was resuspended to $1 \mathrm{ml}$ in double-distilled water. The resulting preparation was used as a stock solution for all bioassays with CrylAc.

Statistical Analysis. The bioassay was repeated 2-4 times for each population, depending on availability of larvae. Concentrations were replicated 3 times for each bioassay (total of 48 larvae per concentration per bioassay). Mortality data were analyzed by probit analysis (Finney 1971) using POLO-PC (LeOra Software 1987). A likelihood ratio test was conducted to test the hypothesis that all $\mathrm{LC}_{\mathbf{P}}$ values (lethal concentration at which a percentage mortality $P$ is attained) were equal. If the hypothesis was rejected, pairwise comparisons were performed and significance was declared if confidence intervals did not overlap (Savin et al. 1977). The significance of differences among slopes was determined by the likelihood ratio test for parallelism (Savin et al. 1977). Larval weights were transformed to percentage growth inhibition relative to the controls, and these data were analyzed by nonlinear regression (PROC NLIN, SAS Institute 1988) fitted to a probit model ( SAS Institute 1988, pp. 1160-1162). The nonlinear probit model used was

$$
\mathbf{E}\left(\mathbf{G I X X )}=\mathrm{c}^{*} \Phi^{*}\left(\mathrm{a}+\mathrm{b}^{*} \mathbf{X}\right),\right.
$$

where $E(G I \mid X)$ is the population mean percentage growth inhibition at the logarithm of the B. thuringiensis protein concentration $\mathrm{X}$, $\mathrm{a}$ and $\mathrm{b}$ are parameters that standardize $\mathrm{GI}$ at $\mathrm{X}$ to a mean of 0 and a standard deviation of 1 , the c parameter is the upper percenage growth inhibition limit and is set at $100 \%$, and $\phi$ is the distribution function of a standard normal random variable. Inverse regression was used to estimate $\mathbf{E C}_{\mathbf{P}}$ (effective concentration at which a percentage growth inhibition level of $P$ is attained) and set confidence intervals on $\mathrm{EC}_{\mathrm{P}}$ (Draper and Smith 1981, pp. 47-51), using an SAS program written by D. Travnicek (Department of Biometry, UNL). First, the model was fitted to the data and confidence bands determined for percentage growth inhibition at various levels of $\mathrm{X}$. Then, for a particular value of $\mathrm{P}(50,95$, or 99$)$, the estimate of $\mathrm{EC}_{\mathrm{P}}$ was found by solving the equation $P=$ $100 \phi\left(\hat{a}+b C_{p}\right)$ for $E_{P}$. To determine confidence limits for $\mathrm{EC}_{\mathbf{P}}$, the level of $\mathrm{EC}_{\mathbf{P}}$ corresponding to the lower and upper confidence bounds $\left(\mathrm{EC}_{\mathrm{L}}\right.$ and $\left.\mathrm{EC}_{\mathrm{U}}\right)$ at a particular level of $\mathrm{P}$ was determined through iteration. That is, $E_{L}$ is that value of $E C$ for which $P_{U}$ $=100 \phi\left(\hat{a}+b_{L}\right)$ and $E_{U}$ is that value of $\mathrm{EC}$ for which $\mathrm{P}_{\mathrm{L}}=100 \phi\left(\hat{\mathrm{a}}+\mathrm{bEC}_{\mathrm{U}}\right)$. The subscripts for $\mathrm{P}$ and $\mathrm{EC}$ are reversed because the lower value for $\mathrm{EC}$ is obtained from the upper confidence band for the fitted curve, whereas the upper value of EC is obtained from the lower confidence band.

\section{Results}

CrylAb. Mortality data for $O$. nubilalis populations exposed to purified $\mathrm{Cryl} \mathrm{Ab}$ protein are presented in Table 2. $\mathrm{LC}_{50}$ values ranged from $2.22 \mathrm{ng} / \mathrm{cm}^{2}$ (North Carolina $\mathrm{F}_{3}$ ) to $7.89 \mathrm{ng} / \mathrm{cm}^{2}$ (Tennessee $\mathrm{F}_{2}$ ). $\mathrm{LC}_{95}$ values ranged from $9.59 \mathrm{ng} / \mathrm{cm}^{2}$ (North Dakota univoltine $F_{1}$ ) to $57.67 \mathrm{ng} / \mathrm{cm}^{2}$ (Illinois $F_{2}$ ). Significant differences $(P<$ 0.05 ) in susceptibility were detected among some of the populations tested, and differences between the most susceptible and most tolerant populations were 4- and 6 -fold at the $\mathrm{LC}_{50}$ and $\mathrm{LC}_{95}$, respectively.

Results regarding growth inhibition of European corn borer larvae treated with CrylAb are presented in Table 3. $\mathrm{EC}_{50}$ values ranged from $0.33 \mathrm{ng} / \mathrm{cm}^{2}$ (North Carolina $\mathrm{F}_{3}$ ) to $1.33 \mathrm{ng} / \mathrm{cm}^{2}$ (Nebraska $\mathrm{F}_{1}$ ). $\mathrm{EC}_{95}$ values ranged from $3.21 \mathrm{ng} / \mathrm{cm}^{2}$ (North Carolina $\mathbf{F}_{3}$ ) to $22.19 \mathrm{ng} / \mathrm{cm}^{2}$ (North Dakota univoltine $\mathbf{F}_{1}$ ). The range of variation in susceptibility indicated by larval growth inhibition (Table 3) was similar to that indicated by mortality (Table 2) - 4- and 7-fold for $\mathrm{EC}_{50}$ and $\mathrm{EC}_{95}$, respectively.

Significant differences in susceptibility, reflected by mortality and growth inhibition, were noted between generations of the same population (Tables 2 and 3). These differences were 2 - to 3 -fold at the $\mathrm{LC}_{50}$ and $\mathrm{EC}_{50}$ and 2- to 4 -fold at the $\mathrm{LC}_{95}$ and $\mathrm{EC}_{95}$, respectively. For mortality data (Table 2), differences among generations of the same population were observed in the Nebraska $F_{2}$ in relation to $F_{3}$ and $F_{14}(\approx 2$-fold) but not to $F_{1}$. However, these differences were significant 
Table 2. Probit analysis of mortality of European corn borer neonates exposed to the CrylAb protein from B. thuringiensis

\begin{tabular}{|c|c|c|c|c|c|c|c|}
\hline Population & Generation & $n$ & Slope $\pm \mathrm{SE}^{a}$ & $\mathrm{LC}_{50}(95 \% \mathrm{FL})^{a b}$ & $\mathrm{LC}_{95}(95 \% \mathrm{FL})^{a b}$ & $\chi^{2}$ & df \\
\hline Colorado & $F_{1}$ & 1,283 & $1.98 \pm 0.14$ bcdef & $4.70(3.38-6.24)$ bcdef & $31.74(20.28-66.82) \mathrm{bcd}$ & $16.17^{c}$ & 6 \\
\hline Illinois & $\mathbf{F}_{2}$ & 1,144 & $1.41 \pm 0.11 a$ & $3.90(2.27-6.16)$ abcdf & $57.67(27.19-252.9) \mathrm{cd}$ & $22.48^{c}$ & 6 \\
\hline Indiana & $F_{1}$ & 1,281 & $2.15 \pm 0.17 b c d e f g$ & $3.94(3.10-4.81) \mathrm{bcd}$ & $23.04(16.76-37.09) \mathrm{bcd}$ & 9.03 & 6 \\
\hline Iowa & $\mathbf{F}_{1}$ & 857 & $1.87 \pm 0.19 \mathrm{bc}$ & $4.97(4.04-5.97) \mathrm{cde}$ & $37.57(27.05-60.07) \mathrm{cd}$ & 2.81 & 6 \\
\hline Italy & $\mathbf{F}_{2}$ & 1,288 & $1.90 \pm 0.15 \mathrm{bcd}$ & $3.16(2.62-3.70) \mathrm{ab}$ & $23.12(18.70-31.60) \mathrm{bc}$ & 3.56 & 6 \\
\hline Italy lab. & $\mathrm{F}_{20}$ & 1,292 & $1.88 \pm 0.16 \mathrm{bc}$ & $3.43(2.61-4.26) \mathrm{abc}$ & $25.48(18.66-41.70)$ bcd & 6.11 & 6 \\
\hline Nebraska & $\mathrm{F}_{1}$ & 1,386 & $1.97 \pm 0.15 \mathrm{bcde}$ & $5.24(4.51-6.03) \mathrm{de}$ & $35.99(27.89-50.09) \mathrm{cd}$ & 4.88 & 7 \\
\hline Nebraska & $\mathrm{F}_{2}$ & 1,718 & $2.27 \pm 0.20 \mathrm{bcdefg}$ & $7.33(5.93-8.75)$ ef & $38.86(28.48-62.74) \mathrm{cd}$ & 7.30 & 6 \\
\hline Nebraska & $\mathbf{F}_{3}$ & 433 & $2.38 \pm 0.32 \mathrm{defg}$ & $3.62(1.67-5.61) \mathrm{abcd}$ & $17.81(10.15-87.34) \mathrm{abc}$ & $27.94^{\circ}$ & 6 \\
\hline Nebraska lab. & $\mathbf{F}_{14}$ & 1,715 & $2.30 \pm 0.16 \mathrm{cdefg}$ & $3.80(2.98-4.63)$ abcd & $19.75(14.77-30.29) \mathrm{bc}$ & 10.85 & 6 \\
\hline N. Dakota (UV) & $\mathrm{F}_{2}$ & 864 & $2.78 \pm 0.30 \mathrm{fg}$ & $2.45(2.02-2.87) \mathrm{a}$ & $9.59(7.68-12.90) \mathrm{a}$ & 9.24 & 6 \\
\hline N. Dakota (BV) & $\mathrm{F}_{1}$ & 1,296 & $1.71 \pm 0.16 \mathrm{ab}$ & $6.00(4.37-7.81) \mathrm{def}$ & $55.20(34.00-125.2) \mathrm{d}$ & 5.52 & 6 \\
\hline N. Carolina & $\mathrm{F}_{1}$ & 1,853 & $1.75 \pm 0.12 b$ & $5.15(4.49-5.86) \mathrm{d}$ & $44.8(34.08-63.66) \mathrm{d}$ & 5.02 & 7 \\
\hline N. Carolina & $\mathbf{F}_{2}$ & 1,292 & $1.90 \pm 0.14 \mathrm{bcde}$ & $3.90(3.12-4.73) \mathrm{bcd}$ & $28.49(20.96-43.43)$ bcd & 6.44 & 6 \\
\hline N. Carolina & $\mathbf{F}_{3}$ & 1,292 & $2.32 \pm 0.14 \mathrm{cdefg}$ & $2.22(1.49-3.05) \mathrm{a}$ & $11.34(7.40-23.73) \mathrm{ab}$ & 9.19 & 6 \\
\hline Missouri & $\mathrm{F}_{3}$ & 1,148 & $2.54 \pm 0.31 \mathrm{efg}$ & $2.66(0.67-4.10) \mathrm{abc}$ & $11.86(7.30-72.47) \mathrm{abc}$ & $28.41^{c}$ & 6 \\
\hline Pennsylvania & $\mathrm{F}_{1}$ & 1,287 & $1.89 \pm 0.13 \mathrm{bcd}$ & $3.67(3.15-4.23) \mathrm{bc}$ & $27.35(21.56-36.82)$ bcd & 2.41 & 6 \\
\hline Tennessee & $\mathrm{F}_{2}$ & 1,148 & $2.98 \pm 0.28 \mathrm{~g}$ & $7.89(6.04-9.84) \mathrm{f}$ & $28.12(19.89-54.34) \mathrm{bcd}$ & $14.51^{\circ}$ & 6 \\
\hline
\end{tabular}

${ }^{a}$ Values followed by the same letter within a column are not significantly different $(P>0.05)$. Significance of differences among slopes determined by likelihood ratio test of equality followed by pairwise comparisons using nonoverlapping fiducial limits (Savin et al. 1977).

${ }^{b} \mathrm{ng}$ CrylAb/ $\mathrm{cm}^{2}$ of treated artificial diet surface.

'Chi-square significant $(P<0.05)$.

only at the $\mathrm{LC}_{50}$ level. The $\mathrm{LC}_{50}$ values of North Carolina $F_{1}$ and $F_{2}$ were greater than those of North Carolina $\mathbf{F}_{3}$ (2-fold). For growth inhibition data $(\mathrm{Ta}-$ ble 3$)$, the 3 consecutive generations tested $\left(F_{1}, F_{2}\right.$, and $F_{3}$ ) were different from each other (2- to 3-fold) for both Nebraska and North Carolina populations. Despite the observed differences among generations of the same population, no differences in susceptibility were observed between the 1st generation tested ( $\mathrm{Ne}$ braska $\mathrm{F}_{1}$ or Italy $\mathrm{F}_{2}$ ) and the corresponding laboratory colony in culture for multiple generations (Nebraska $\mathbf{F}_{14}$ or Italy $\mathbf{F}_{20}$ ).

CrylAc. Mortality data for European corn borer challenged with CrylAc protein are presented in Ta- ble 4. $\mathrm{LC}_{50}$ values ranged from $0.20 \mathrm{ng} / \mathrm{cm}^{2}\left(\mathrm{Ital} \mathrm{F}_{2}\right.$ and Italy $\mathbf{L a b} \mathbf{F}_{20}$ ) to $0.78 \mathrm{ng} / \mathrm{cm}^{2}$ (Illinois $\mathbf{F}_{2}$ ). $\mathbf{L C}_{95}$ values ranged from $1.15 \mathrm{ng} / \mathrm{cm}^{2}$ (Iowa $F_{1}$ ) to $4.53 \mathrm{ng} / \mathrm{cm}^{2}$ (Illinois $\mathbf{F}_{2}$ ). These values represent a 4-fold variation in susceptibility to CrylAc at both the $\mathrm{LC}_{50}$ and $\mathrm{LC}_{95}$.

Results regarding growth inhibition of corn borer larvae treated with CrylAc are presented in Table $5 . \mathrm{EC}_{50}$ values ranged from $0.05 \mathrm{ng} / \mathrm{cm}^{2}$ (Italy Lab $F_{20}$ ) to 0.13 $\mathrm{ng} / \mathrm{cm}^{2}$ (Indiana $\mathrm{F}_{1}$ ). $\mathbf{E C}_{95}$ values ranged from $0.36 \mathrm{ng} /$ $\mathrm{cm}^{2}\left(\right.$ Iowa $F_{1}$ ) to $1.56 \mathrm{ng} / \mathrm{cm}^{2}$ (North Carolina $F_{1}$ ). The range of variation in CrylAc susceptibility indicated by larval growth inhibition (Table 5) again was comparable with that indicated by larval mortality (Table 4 ) -2-and 4-fold for $\mathrm{EC}_{50}$ and $\mathrm{EC}_{95}$, respectively.

Table 3. Nonlinear regression of growth inhibition fitted to a probit model for European corn borer neonates exposed to the Cry 1 Ab protein from $B$. thuringiensis

\begin{tabular}{|c|c|c|c|c|c|}
\hline Population & Generation & $n$ & $\begin{array}{c}\text { Pairwise } \\
\text { comparison }^{a}\end{array}$ & $\mathrm{EC}_{50}(95 \% \mathrm{FL})^{b}$ & $\mathrm{EC}_{95}(95 \% \mathrm{FL})^{b}$ \\
\hline Colorado & $F_{1}$ & 1,283 & $\mathrm{e}$ & $0.67(0.56-0.78)$ & $5.21(3.36-7.56)$ \\
\hline Illinois & $\mathrm{F}_{2}$ & 1,144 & $\mathrm{~d}$ & $0.60(0.54-0.66)$ & $14.05(10.69-18.16)$ \\
\hline Indiana & $F_{1}$ & 1,281 & $\mathrm{~cd}$ & $0.54(0.44-0.64)$ & $7.93(4.79-12.33)$ \\
\hline Iowa & $\mathrm{F}_{1}$ & 857 & efg & $0.84(0.69-0.99)$ & $14.01(8.54-21.59)$ \\
\hline Italy & $F_{2}$ & 1,288 & $a b c$ & $0.35(0.31-0.38)$ & $4.97(4.00-6.11)$ \\
\hline Italy lab. & $F_{20}$ & 1,292 & $\mathrm{bc}$ & $0.34(0.31-0.43)$ & $8.07(5.35-11.83)$ \\
\hline Nebraska & $\mathrm{F}_{\mathrm{l}}$ & 1,386 & $\mathrm{~h}$ & $1.33(0.93-1.38)$ & $8.10(4.90-12.19)$ \\
\hline Nebraska & $\mathrm{F}_{2}$ & 1,718 & $\mathrm{efg}$ & $0.78(0.60-0.99)$ & $12.86(6.58-22.62)$ \\
\hline Nebraska & $\mathrm{F}_{3}$ & 433 & bed & $0.38(0.22-0.57)$ & $9.02(3.21-21.99)$ \\
\hline Nebraska lab. & $F_{14}$ & 1,715 & gh & $0.99(0.75-1.30)$ & $6.71(3.39-11.38)$ \\
\hline N. Carolina & $\mathrm{F}_{1}$ & 1,853 & efg & $0.75(0.66-0.86)$ & $7.95(5.58-10.81)$ \\
\hline N. Carolina & $\mathrm{F}_{2}$ & 1,292 & $\mathrm{~h}$ & $1.07(0.90-1.27)$ & $5.79(3.69-8.33)$ \\
\hline N. Carolina & $\mathrm{F}_{3}$ & 1,292 & a & $0.33(0.31-0.35)$ & $3.21(2.72-3.77)$ \\
\hline N. Dakota (BV) & $\mathrm{F}_{2}$ & 864 & bcd & $0.48(0.39-0.58)$ & $4.47(2.65-6.98)$ \\
\hline N. Dakota (UV) & $\mathrm{F}_{1}$ & 1,296 & fg & $0.98(0.73-1.29)$ & $22.19(10.38-42.07)$ \\
\hline Missouri & $\mathrm{F}_{2}$ & 1,148 & $\mathrm{ab}$ & $0.34(0.29-0.39)$ & $5.26(3.65-7.38)$ \\
\hline Pennsylvania & $\mathrm{F}_{1}$ & 1,287 & ef & $0.70(0.60-0.82)$ & $6.58(4.20-9.64)$ \\
\hline Tennessee & $\mathbf{F}_{2}$ & 1,148 & $\mathrm{efg}$ & $0.79(0.73-0.85)$ & $10.49(8.42-12.87)$ \\
\hline
\end{tabular}

Data not fitting the probit model $(\mathrm{P}<0.05)$ not included.

${ }^{a}$ An overall $F$-test indicated that the parameters were not equal for all populations tested. Therefore, pairwise comparisons were conducted to determine whether the parameters of the nonlinear probit model differed significantly $(P<0.05)$ for any particular population pair. Values followed by the same letter within a column indicate populations that could be fit with common parameters.

${ }^{b} \mathrm{ng} \mathrm{Cry} 1 \mathrm{Ab} / \mathrm{cm}^{2}$ of treated artificial diet surface. 
Table 4. Probit analysis of mortality of European com borer neonates exposed to the Cry 1 Ac protein from B. thuringiensis

\begin{tabular}{|c|c|c|c|c|c|c|c|}
\hline Population & Generation & $n$ & Slope $\pm \mathrm{SE}^{a}$ & $\mathrm{LC}_{50}(95 \% \mathbf{F L})^{a b}$ & $\mathrm{LC}_{95}(95 \% \mathrm{FL})^{a h}$ & $x^{2}$ & $\mathrm{df}$ \\
\hline Colorado & $\mathbf{F}_{1}$ & 1,160 & $2.09 \pm 0.13 \mathrm{ab}$ & $0.33(0.25-0.43)$ abcd & $2.02(1.42-3.34) \mathrm{abc}$ & 13.24 & 6 \\
\hline Illinois & $F_{2}$ & 1,288 & $2.15 \pm 0.15 \mathrm{ab}$ & $0.78(0.67-0.89) \mathrm{e}$ & $4.53(3.68-5.87) \mathrm{d}$ & 5.26 & 6 \\
\hline Indiana & $F_{1}$ & 1,150 & $1.19 \pm 0.12 \mathrm{a}$ & $0.40(0.28-0.53) \mathrm{cd}$ & $2.90(1.98-5.09) \mathrm{bcd}$ & 13.48 & 6 \\
\hline Iowa & $\mathrm{F}_{1}$ & 1,292 & $2.23 \pm 0.17 \mathrm{ab}$ & $0.21(0.17-0.25) \mathrm{a}$ & $1.15(0.93-1.47) \mathbf{a}$ & 3.63 & 6 \\
\hline Italy & $\mathrm{F}_{2}$ & 1,282 & $1.90 \pm 0.11 \mathrm{a}$ & $0.20(0.16-0.25) \mathrm{a}$ & $1.46(1.08-2.19) \mathrm{ab}$ & 9.20 & 6 \\
\hline Italy lab. & $F_{20}$ & 1,290 & $1.76 \pm 0.12 a$ & $0.20(0.14-0.26) \mathrm{ab}$ & $1.72(1.21-2.78) \mathrm{abc}$ & 10.00 & 6 \\
\hline Nebraska $\left(F_{1}\right)$ & $\mathrm{F}_{1}$ & 1,288 & $1.82 \pm 0.11 \mathrm{a}$ & $0.29(0.21-0.37) \mathrm{abc}$ & $2.30(1.62-3.73) \mathrm{bcd}$ & 11.45 & 6 \\
\hline Nebraska lab. & $\mathrm{F}_{14}$ & 1,291 & $2.02 \pm 0.12 \mathrm{ab}$ & $0.32(0.24-0.42) \mathrm{abc}$ & $2.09(1.47-3.51) \mathrm{abc}$ & $14.54^{c}$ & 6 \\
\hline N. Dakota (BV) & $F_{2}$ & 862 & $2.12 \pm 0.17 \mathrm{ab}$ & $0.53(0.42-0.66) \mathrm{d}$ & $3.19(2.38-4.76) \mathrm{cd}$ & 6.28 & 6 \\
\hline North Carolina & $\mathbf{F}_{1}$ & 2,135 & $1.83 \pm 0.09 \mathrm{a}$ & $0.33(0.25-0.42)$ bcd & $2.64(1.89-4.17)$ bcd & $17.45^{\circ}$ & 6 \\
\hline North Carolina & $F_{2}$ & 1,001 & $2.52 \pm 0.19 b$ & $0.42(0.30-0.55) \mathrm{cd}$ & $1.88(1.31-3.37) \mathrm{abc}$ & $15.95^{\circ}$ & 6 \\
\hline Pennsylvania & $\mathrm{F}_{1}$ & 1,420 & $1.95 \pm 0.10 \mathrm{ab}$ & $0.42(0.30-0.57) \mathrm{cd}$ & $2.97(1.93-5.72) b c$ & $24.58^{\circ}$ & 6 \\
\hline Tennessee & $\mathrm{F}_{2}$ & 1,285 & $2.33 \pm 0.14 b$ & $0.44(0.36-0.52) \mathrm{cd}$ & $2.23(1.73-3.12) b c$ & 8.50 & 6 \\
\hline
\end{tabular}

${ }^{a}$ Values followed by the same letter within a column are not significantly different $(P \geq 0.05)$. Significance of differences among slopes determined by likelihood ratio test of equality followed by pairwise comparisons using nonoverlapping fiducial limits (Savin et al. 1977).

${ }^{b} \mathrm{ng}$ Cryl Ac/ $\mathrm{cm}^{2}$ of treated artificial diet surface.

${ }^{c}$ Chi-square significant $(P<0.05)$.

Differences in susceptibility to Cryl Ac among generations within a population (Tables 4 and 5 ) were more subtle $(<2$-fold $)$ than for CrylAb. In fact, significance was achieved only at the $\mathrm{EC}_{50}$ level, between North Carolina $F_{1}$ and $F_{2}$ (Table 5). However, only 2 generations were evaluated with CrylAc, which may have decreased the likelihood of observing significant differences among populations. As with CrylAb, no differences were noted among generations of recently collected insects (Nebraska $\mathrm{F}_{1}$ and Italy $\mathrm{F}_{2}$ ) and laboratory colonies in culture for many generations ( $\mathrm{Ne}$ braska $F_{14}$ and Italy $F_{20}$ ). These results suggest that although variation in susceptibility to $B$. thuringiensis toxins were observed from generation to generation, laboratory culturing of European corn borers for multiple generations does not seem to affect susceptibility to $B$. thuringiensis. Overall, susceptibility to CrylAc from MVP Biopesticide was about an order of magnitude greater than to purified Cryl Ab (Tables 2-5).

Significant differences were noted for probit line slopes, both among generations within a particular population and among geographically distinct popu- lations (Tables 2 and 4). However, the range of variation was relatively small $(<2$-fold $)$. The slopes of concentration-mortality lines generated for European corn borer in response to $B$. thuringiensis toxins (1.73.0 , Tables 2 and 4 ) were $\approx 2$-fold less steep than those observed for corn borer treated with Fipronil (B.D.S., unpublished data), supporting other observations that shallow slopes are characteristic of the response of most insects to microbial insecticides (Burges 1971, Stone and Sims 1993).

\section{Discussion}

Although interpopulation variation in susceptibility to CrylAb and CrylAc was observed, the magnitude of the differences was small (i.e., 2-7-fold, at the $\mathrm{LC}_{50}$ and $\mathrm{EC}_{50}$ ) and comparable with the variation observed among generations within populations (i.e., $\left(\leq 3\right.$-fold at the $\mathrm{LC}_{50}$ and $\left.\mathbf{E C}_{50}\right)$. Additionally, susceptibility to $B$. thuringiensis was not related to pheromone race, voltine ecotype, or geographic location. Because verification of pheromone strain and ecotype

Table 5. Nonlinear regression of growth inhibition fitted to a probit model for European corn borer neonates exposed to the Cry 1 Ac protein from $B$. thuringiensis

\begin{tabular}{|c|c|c|c|c|c|}
\hline Population & Generation & $n$ & $\begin{array}{c}\text { Pairwise } \\
\text { comparison }^{a}\end{array}$ & $\mathbf{E C}_{50}(95 \% \mathrm{FL})^{b}$ & $\mathrm{EC}_{95}(95 \% \mathrm{FL})^{b}$ \\
\hline Colorado & $F_{1}$ & 1,160 & $\mathrm{~b}$ & $0.076(0.072-0.081)$ & $0.44(0.37-0.51)$ \\
\hline Illinois & $\mathrm{F}_{2}$ & 1,288 & $\mathrm{f}$ & $0.11(0.083-0.14)$ & $1.56(0.78-2.83)$ \\
\hline Indiana & $F_{1}$ & 1,150 & $g$ & $0.13(0.12-0.14)$ & $0.66(0.53-0.81)$ \\
\hline Iowa & $\mathrm{F}_{\mathrm{I}}$ & 1,292 & $\mathrm{~d}$ & $0.071(0.064-0.077)$ & $0.36(0.29-0.45)$ \\
\hline Italy lab. & $\mathrm{F}_{20}$ & 1,290 & $\mathrm{a}$ & $0.050(0.045-0.055)$ & $0.44(0.35-0.54)$ \\
\hline Italy & $\mathrm{F}_{2}$ & 1,282 & $\dot{a}$ & $0.052(0.044-0.058)$ & $0.45(0.33-0.60)$ \\
\hline Nebraska & $F_{1}^{2}$ & 1,288 & $\mathrm{c}$ & $0.079(0.070-0.089)$ & $0.84(0.62-1.12)$ \\
\hline Nebraska lab. & $\mathrm{F}_{14}$ & 1,291 & bed & $0.069(0.066-0.073)$ & $0.48(0.42-0.55)$ \\
\hline North Carolina & $\mathrm{F}_{1}$ & 2,135 & bc & $0.067(0.059-0.080)$ & $0.71(0.49-0.99)$ \\
\hline North Carolina & $\mathrm{F}_{2}$ & 1,001 & $\mathrm{e}$ & $0.11(0.096-0.13)$ & $0.79(0.51-1.13)$ \\
\hline N. Dakota (BV) & $\mathbf{F}_{2}$ & 862 & $\mathrm{e}$ & $0.12(0.097-0.15)$ & $1.18(0.67-1.90)$ \\
\hline Tennessee & $\mathrm{F}_{2}$ & 1,285 & $\mathrm{e}$ & $0.11(0.10-0.11)$ & $0.65(0.56-0.76)$ \\
\hline
\end{tabular}

Data not fitting the probit model $(P<0.05)$ not included.

${ }^{a}$ An overall $F$-test indicated that the parameters were not equal for all populations tested. Therefore, pairwise comparisons were conducted to determine whether the parameters of the nonlinear probit model differed significantly $(P<0.05)$ for any particular population pair. Values followed by the same letter within a column indicate populations that could be fit with common parameters.

${ }^{b} \mathrm{ng}$ Cryl $\mathrm{Ab} / \mathrm{cm}^{3}$ of treated artificial diet surface. 
was not performed, it may be inappropriate to conclude that these differences in susceptibility do not exist. However, based on known distributions of these genetic variants, our results do not indicate any strong differences among strains.

In a similar study, Stone and Sims (1993) found considerable interpopulation variation in $B$. thuringiensis susceptibility among U.S. populations of the corn earwom, Helicoverpa zea, and tobacco budworm, Heliothis virescens (16- and 4-fold, respectively). These data were reexamined by Sims et al. (1996), who suggested that interpopulation variation in $B$. thuringiensis susceptibility in these species may reflect nongenetic variation or sampling error, because the populations tested represented a small sample, taken at one point in time, of considerably larger multivoltine populations. Similar levels of variability in $B$. thuringiensis susceptibility were noted previously for the European corn borer using different bioassay techniques (Siegfried et al. 1995). Rossiter et al. (1990) found significant variation in $B$. thuringiensis susceptibility among 3 populations of gypsy moth, Lymantria dispar. A significant proportion of that variation was among siblings within a family, whereas differences among families (caused by genetic and mean maternal effect differences among families) accounted for only $16 \%$ of the total variation.

As reported for the gypsy moth (Rossiter et al. 1990), the variation in susceptibility to $B$. thuringiensis in $\mathrm{Eu}^{-}$ ropean corn borers observed in the current study may reflect vigor differences in growth and developmental capability, attributes that are the product of both genotype and the maternally determined nutritional status of the egg. Similar variation in LC values has been reported among repeated bioassays with $B$. thuringiensis proteins against larvae from single strains of Colorado potato beetle, Leptinotarsa decemlineata, and diamondback moth, Plutella xylostella. For a laboratory strain of the Colorado potato beetle tested with $B$. thuringiensis subsp. tenebrionis over an 83-wk period, $\mathrm{LC}_{50}$ values ranged from 20 to $255 \mathrm{mg}(\mathrm{AI}) / \mathrm{ml}$, a 13-fold difference in response to the $B$. thuringiensis toxin (Robertson et al. 1995). Similarly, for a diamondback moth population tested with B. thuringiensis subsp. kurstakii for $24 \mathrm{wk}$, $\mathrm{LC}_{50}$ values varied from 0.18 to 0.66 ( $\approx 4$-fold) (Robertson et al. 1995). Based on the data from the current study, it is not possible to determine whether the observed differences in susceptibility among corn borer populations are partially heritable or simply reflect environmental influences upon response of insects to the $B$. thuringiensis toxins. However, the generation-to-generation variation in response to the $B$. thuringiensis toxins suggests that at least part of the variation is caused by nonheritable factors associated with repeated bioassays. Overall, there was no indication of increased tolerance associated with prior exposure to $B$. thuringiensis selection or to long-term rearing on artificial diet. The results of this study support the assumption that the European corn borer remains susceptible to CrylAb and CrylAc from $B$. thuringiensis across most of its geographic distribution.

Intrapopulation variation in response to chemical or microbial insecticides is a common phenomenon when any bioassay is repeated (Robertson et al. 1995), and the extent of both intra- and interpopulation natural variation in susceptibility to a given pesticide should be investigated before biologically important changes can be identified with any certainty. Ideally, this should be done before the product is used commercially rather than after resistance is already widespread. Knowledge of the natural variation in response to $B$. thuringiensis among corn borer populations before widespread commercial use of $\mathrm{Bt}$ corn is necessary to avoid unwarranted concerns about resistance to $B$. thuringiensis in field surveys of European corn borer populations.

The diet surface treatment bioassay used in this study provided reliable and consistent results and required significantly less purified $B$. thuringiensis protein than a comparable diet incorporation assay. Testing insects with purified $B$. thuringiensis toxins is recommended over commercial formulations containing these proteins because the purified forms may elucidate shifts in susceptibility to transgenic plants more readily than a complex mixture of several proteins, spores, and formulation ingredients (Stone and Sims 1993). For example, although the MVP formulation used in this study should have been devoid of potentially toxic inert ingredients, we are not certain whether the apparently greater potency of CrylAc was inherent to the toxin or an artifact of the formulation. Our results are inconsistent with previous comparisons of European corn borer susceptibility to CrylAb and CrylAc (Denolf et al. 1993) that indicated higher susceptibility to CrylAb. Further testing with purified CrylAc would be required to compare toxicity of the 2 toxins adequately.

Growth inhibition data (established by weighing individual larvae) were more sensitive than mortality data (which included both extreme growth inhibition and mortality responses) for detecting the sublethal effects of the $B$. thuringiensis toxins (i.e., $\mathbf{E C}_{50}$ values were one order of magnitude lower than $\mathrm{LC}_{50}$ values). However, there was no clear advantage of using this response instead of mortality data. The range of variation in susceptibility among European corn borer populations was similar between the 2 response criteria, and because mortality data are easier and faster to collect, this response should be more appropriate for large-scale monitoring. However, scoring this type of bioassay requires some training to determine visually which larvae are severely stunted ( $\leq 0.1 \mathrm{mg}$ ), although the chance for error in interpretation could be minimized by concurrently testing sample larvae on control diet to provide a direct size comparison (Sims et al. 1996).

Development of $B$. thuringiensis baseline susceptibility data before widespread commercial release of transgenic Bt corn represents the first step toward the development of a monitoring program designed to identify resistant European corn borer populations should they develop. These data also may provide information that will allow development of diagnostic bioassays that would be more efficient in detection of populations resistant to $B$. thuringiensis. Monitoring for potential resistance in corn borer populations would be facilitated by the establishment of such a 
diagnostic bioassay, and future efforts should concentrate on development of this critical tool for effectively monitoring the resistance status of European corn borer field populations to $B$. thuringiensis as they become exposed to transgenic Bt corn.

\section{Acknowledgments}

The authors acknowledge the contributions of cooperators who generously provided their time in collecting $O$. nubilalis for inclusion in this study-K. Kinney (Colorado State University), M. Weiss (North Dakota State University), R. Seymor (University of Nebraska), W. Hutchison (University of Minnesota), J. White (Ciba Seeds), R. Hellmich (USDA-ARS, Ames, IA), L. Bledsoe (Purdue University), S. Inch and P. Inch (Selinsgrove, PA), J. Van Duyn (North Carolina State Unviersity), J. Overman (DeKalb Genetics), and A. Keaster and C. Sorensen (University of Missouri). J. Witkowski and L. Meinke provided critical review of an early draft of the manuscript. Funding for this work was provided by Pioneer Hi-Bred International, DeKalb Genetics, PGS, Monsanto, Novartis Seeds, Mycogen Seeds, ICI Seeds, and the $B$. thuringiensis Resistance Management Working Group.

\section{References Cited}

Burges, H. D. 1971. Possibilities of pest resistance to microbial control agents, pp. 445-457. In H. D. Burges and N. W. Hussey [eds.], Microbial control of insects and mites. Academic, London.

Dennehey, T. J. 1987. Decision-making for managing pest resistance to pesticides, pp. 118-126. In M. G. Ford, D. W. Holloman, B.P.S. Khanbay, and R. M. Sawicki [eds.], Combating resistance to xenobiotics: biological and chemical approaches. Ellis Horwood, Chichester, England.

Denolf, P., S. Jansens, M. Peferoen, D. Degheele, and J. Van Rie. 1993. Two different Bacillus thuringiensis delta-endotoxin receptors in the midgut brush border membrane of the European corn borer, Ostrinia nubilalis (Hübner) (Lepidoptera: Pyralidae). Appl. Environ. Microbiol. 59: $1828-1837$.

Draper, N. R., and H. Smith. 1981. Applied regression analysis. Wiley, New York.

Finney, D. J. 1971. Probit analysis. Cambridge University Press, England.

Fischhoff, D. A. 1996. Insect-resistant crop plants, pp. 214227. In G. J. Persley [ed.], Biotechnology and integrated pest management. CAB International, Wallingford, UK.

Glover, T. J., J. J. Knodel, P. S. Robbins, C. J. Eckenrode, and W. L. Roelofs. 1991. Gene flow among three races of European corn borers (Lepidoptera: Pyralidae) in New York State. Environ. Entomol. 20: 1356-1362.

Gould, F., A. Anderson, A. Reynolds, L. Bumgardner, and W. Moar. 1995. Selection and genetic analysis of a Heliothis virescens (Lepidoptera: Noctuidae) strain with high levels of resistance to Bacillus thuringiensis toxins. J. Econ. Entomol. 88: 1545-1559.

Guthrie, W.D., E. S. Raun, F. F. Dicke, G. R. Pesho, and S. W. Carter. 1965. Laboratory production of European corn borer egg masses. Iowa State J. Sci. 40: 665-683.

Hokkanen, H. M., and C. H. Wearing. 1994. The safe deployment of Bacillus thuringiensis genes in crop plants: conclusions and recommendations of OECD Workshop on ecological implications of transgenic crops containing Bt toxin genes. Biocontrol Sci. Technol. 4: 399-404.

King, E. G., G. G. Hartley, D. F. Martin, and M. L. Laster. 1985. Large-scale rearing of a sterile backcross of the tobacco budworm (Lepidoptera: Noctuidae). J. Econ. Entomol. 78: 1166-1172.

Klun, J. A., and M. D. Huettel. 1988. Genetic regulation of sex pheromone production and response: interaction of sympatric pheromonal races of the European corn borer, Ostrinia nubilalis (Lepidoptera: Pyralidae). J. Chem. Ecol. 14: 2047-2061.

Leahy, T. C., and D. A. Andow. 1994. Egg weight, fecundity, and longevity are increased by adult feeding in Ostrinia nubilalis (Hübner) (Lepidoptera: Pyralidae). Ann. Entomol. Soc. Am. 87: 342-349.

LeOra Software. 1987. POLO-PC. A user's guide to probit and logit analysis. Berkeley, CA.

Lewis, L. C., and R. E. Lynch. 1969. Rearing the European corn borer on corn leaf and wheat germ diets. Iowa State J. Sci. 44: 9-14.

Mason, C. E., M. E. Rice, D. D. Calvin, J. W. Van Duyn, W. B. Showers, W. D. Hutchinson, J. F. Witkowski, R. A. Higgins, D. W. Onstad, and G. P. Dively. 1996. European corn borer ecology and management. North Central Regional. Publication 327. Iowa State University, Ames.

Robertson, J. L., H. K. Preisler, S. S. Ng, L. A. Hickle, and W.D. Gelernter. 1995. Natural variation: a complicating factor in bioassays with chemical and microbial pesticides. J. Econ. Entomol. 88: 1-10

Rossiter, M., W. G. Yendol, and N. R. Dubois. 1990. Resistance to Bacillus thuringiensis in gypsy moth (Lepidoptera: Lymantriidae) : genetic and environmental causes. J Econ. Entomol. 83: 2211-2218.

SAS Institute. 1988. SAS procedures guide, release $6.03 \mathrm{ed}$ SAS Institute, Cary, NC.

Savin, N. E., J. L. Robertson, and R. M. Russell. 1977. A critical evaluation of bioassay in insecticide research likelihood ratio tests of dose-mortality regression. Bull. Entomol. Soc. Am. 23: 257-266.

Showers, W. B. 1993. Diversity and variation of European corn borer populations, pp. 287-309. In K. C. Kim and B. A. McPheron [eds.], Evolution of insect pests/patterns of variation. Wiley, New York.

Siegfried, B. D., P.C.R.G. Marçon, J. F. Witkowski, R. J. Wright, and G. W. Warren. 1995. Susceptibility of field populations of the European corn borer, Ostrinia nubilalis (Hubner) (Lepidoptera: Pyralidae), to the microbia insecticide Bacillus thurinigiensis Berliner. J. Agric. Entomol. 12: 257-263.

Sims, S. R., J. T. Greenplate, T. B. Stone, M. A. Caprio, and F. L. Gould. 1996. Monitoring strategies for early detection of Lepidoptera resistance to Bacillus thuringiensis insecticidal proteins, pp. 229-242. In T. M. Brown [ed.], Molecular genetics and evolution of pesticide resistance. Symposium Series. American Chemical Society, Washington, DC

Stone, T. B., and S. R. Sims. 1993. Geographic susceptibility of Heliothis virescens and Helicoverpa zea (Lepidoptera: Noctuidae) to Bacillus thuringiensis. J. Econ. Entomol. 86 989-994.

Tabashnik, B. E. 1994. Evolution of resistance to Bacillus thuringiensis. Annu. Rev. Entomol. 39: 47-79.

Received for publication 16 March 1998; accepted 6 January 1999 